\author{
R.B. Zhashkenova ${ }^{1, *}$, Ye.B. Aimagambetov ${ }^{2}$, T.P. Pritvorova ${ }^{3}$, A.T. Omarova ${ }^{4}$, G.Ye. Nakipova ${ }^{5}$ \\ ${ }^{1,2,4,5}$ Karaganda Economic University of Kazpotrebsoyuz, Karaganda, Kazakhstan \\ ${ }^{3}$ Karagandy University of the name of academician E.A. Buketov, Kazakhstan \\ ${ }^{1}$ zhashkenova2015@mail.ru, ${ }^{2}$ rector@keu.kz,pritvorova_@mail.ru, ${ }^{4}$ ainuraphd@mail.ru, ${ }^{5}$ nakipovage@mail.ru \\ ${ }^{1}$ https://orcid.org/0000-0001-6038-8180, ${ }^{2}$ http://orcid.org/0000-0003-4590-8242, ${ }^{3}$ http://orcid.org/0000-0002-6306- \\ 3960, ${ }^{4}$ https://orcid.org/0000-0001-9808-4908, ${ }^{5}$ http://orcid.org/0000-0001-6754-246X \\ ${ }^{2}$ Scopus Author ID: 55816012800, ${ }^{3}$ Scopus Author ID: 55982396200 \\ ${ }^{2}$ Researcher ID: U-7564-2018
}

\title{
Transformation of university strategies in the digitalization of the educational space
}

\begin{abstract}
Object: is to analyze the strategy of universities in the context of the digital economy, where the emphasis is on transforming the strategy of universities in the field of their interaction with the state and the business community in the context of digitalization.

Methods: research methodology is a set of methods, mechanisms, principles, measures to improve the efficiency of development and use of new information and communication technologies, which are a prerequisite for the further development of education and digital pedagogy, in the implementation of an effective information educational environment, which is the basis for the development of any university.

Findings: authors for such indicators as the cost of services rendered and goods sold, produced on their own by the universities of the Republic of Kazakhstan and the internal costs of R\&D in the Republic of Kazakhstan, hypothesized that there is a connection between: the total costs of ICT and the cost of services provided by the universities of the Republic of Kazakhstan ; ICT expenditures and scientific R\&D expenditures in the Republic of Kazakhstan.

Conclusions: based on the conducted regression analysis, the author of the article concluded that:

1) with an increase in internal R\&D costs by $1 \%$ of its average level, the total costs of ICT will increase by $1.342 \%$ of their average level, with the cost of services rendered and goods sold by themselves produced by the universities of the Republic of Kazakhstan unchanged;

2) with an increase in the cost of services rendered and goods sold, produced on their own, by the universities of the Republic of Kazakhstan by $1 \%$ of their average level, the total cost of ICT will increase by $0.025 \%$ of its average level, while the volume of internal R\&D costs remains unchanged.
\end{abstract}

Keywords: digitalization, business community, strategy, education system, innovation, innovativeness, competitiveness, educational process, management, quality, educational space.

\section{Introduction}

The relevance and validity of the choice of the research topic is that in recent decades the world has rapidly evolved towards a new type of economy, where the main tool is the formation of digital technologies, the potential of which is largely associated with the results of the creation and development of the information society (Vedutaet al., 2017, 43). The growing role of information technology in the private and public sectors is the basis for the transition to a digital state.

What happens under the influence of the spreading digital transformation of society determines the emergence of new theoretical concepts. At the end of the 20th century, we talked about building a postindustrial society, and at the beginning of the 21 st century, about the transition to a knowledge society, and now about a new industrialization and digital economy. Recognizing the importance of computerization of society and the development of digital technologies in determining long-term economic growth, the government and state bodies of Kazakhstan are actively involved in the development of this sphere as one of the main directions of state policy.

In an era of rapid technological development, digitalization and the formation of a digital culture are of particular importance for ensuring the well-being of citizens and the socio-economic stability of the state. Today, the economy and society of Kazakhstan must adapt to modern conditions. The measures taken by the government to develop digitalization in Kazakhstan formed the basis for further measures in the field of digital transformation in the education system.

The development of science and education is an important priority for socio-economic modernization, achieving competitiveness of the economy and Kazakhstan becoming one of the 30 developed countries of

\footnotetext{
*Corresponding author.

E-mail address: zhashkenova2015@mail.ru
} 
the world. The key tasks of the modern system of education, training and retraining of personnel were emphasized by the First President of the country - the Leader of the nation N.A. Nazarbayev in his annual Messages to the people of Kazakhstan "Strategy" Kazakhstan - 2050: a new political course of a successful state "(Kazakhstan's way - 2050, 2014)and“"Kazakhstan's way - 2050: a common goal, common interests, common future " (Strategy 2050, 2012).

The implementation of state policy in the field of informatization of higher education on the basis of ICT is being developed at the university level. All universities have their own educational informatization programs aimed at:

- development of information and communication infrastructure of universities;

- The concept of continuous training in open distance learning;

- The concept of creating a university information and educational environment and the development of digital educational resources.

The Concepts of informatization of higher education on the basis of modern ICT, approved by the Academic Councils of universities, are specified in Education Informatization Programs and Action Plans for their implementation.

\section{Literature Review}

At present, in many countries, digitalization is a strategic development priority. The State Program "Digital Kazakhstan" noted that the new digital revolution is changing today's methods of production, supply chain and value chain (State program, 2017).

The state and the business community of the Republic of Kazakhstan are implementing a number ofprogram initiatives, the purpose of which is to modernize the country in various directions under the conditions of Industry 4.0. One of the priority tasks is the creation of a new model of economic growth, which will strengthen the competitiveness of Kazakhstan in the world through such important tasks as the creation of a "smart" education system (smart nation) that can prepare the younger generation for life in the new digital economy: specialists, high-class analysts, specialists-generators of new ideas who can think and work creatively and critically in all areas of activity (Nurtayeva et al., 2019, 27).

The field of science is an essential part of the national heritage, a fundamental resource for the country's economic and social transformations. The scientific potential largely determines the country's place in the world community, the prospects for competition in the foreign market, and the possibilities in solving its internal problems (Yuvitsa, 2015, 247).

Modern universities have the necessary potential for education, research, innovation and cultural development. However, for effective work in this direction, universities need to cooperate with business, government and other interested parties. The process of such interaction "university - business - state" is presented in the works of G. Itskovits within the framework of the concept of the Triple Helix (Etzkowitz et al., $2007,14)$. But the basis for university management should be an information-analytical system (Chinayeva, 2017, 60).

So, in higher education, for example, in the USA, organizational development grew out of the "movement for quality rooted in work to improve the quality of work, productivity and improve educational processes (Sutherland, 2018, 264).

According to Yu.N.Kulyutkina, knowledge should be systematically organized, be categorical (act as general approaches, principles and key ideas) and at the same time be specific, flexible and dynamic (quickly rebuild and change under the influence of a changing situation) (Kuluytkin et al., 2002, 44).

The founder of the classical school of management, Henri Fayolle, believed that the knowledge gained during management training in educational institutions does not meet the requirements that are so necessary in effective business management (Fayol, 2012, 8).

Vakhstein V.S. in his scientific publications notes that higher education is often considered by employers as a necessary initial stage for mastering the profession. The need for lifelong learning at the mass level is becoming one of the priorities of the educational policy of OECD countries (Vakhshtayn et al., 2014, 33).

In this regard, a serious problem for the state is the need for full integration into the emerging global sphere of education, taking into account national interests, characteristics and traditions of the development of educational systems.

\section{Methods}

The research methodology is a complex of methods, mechanisms, principles, measures to improve the efficiency of development and use of new information and communication technologies, which are a prereq- 
uisite for the further development of education and digital pedagogy, in the implementation of an effective information educational environment, which is the basis for the development of any university.

The study was carried out using general methods used in economic science, based on a logical description of the components and functions of digital technologies in education, reflecting their essential properties using a systematic approach, providing the necessary depth of study of the scientific problem. The sources of the study were theoretical and analytical articles, works of Kazakhstani and foreign authors, which consider the issues of digitalization of the economy.

When writing the article, the authors used general scientific methods of cognition:

- statistical, normative analysis, synthesis, analogy, generalization,

- empirical-theoretical (collection, study and comparison of data),

- methods of scientific knowledge (historical-legal, formal-logical, systemic, comparative-legal).

When processing and organizing data, the methods of grouping and classification, as well as methods of mathematical modeling, were used. To build an econometric model based on the estimation of the parameters of the two-factor regression equation, an analysis was carried out using the least squares method. One of the indicators that can be used to assess the degree of response of one variable to a change in another is the coefficient of elasticity. In our case, it makes it possible to show the ability of the total costs of ICT to change depending on the change in internal costs for R\&D and the cost of services rendered and goods sold, produced on their own, by universities of Kazakhstan.

The conclusions and results of the study were presented using a graphical method of presenting the results obtained. The methods used for the study of economic phenomena and processing of primary information in their totality made it possible to ensure the reliability of the analysis and the validity of the conclusions.

The information base of the research was made up of legislative and other normative acts of the Republic of Kazakhstan, statistical data of the Agency of the Republic of Kazakhstan on Statistics, analytical materials, materials of scientific economic literature and periodicals, materials of scientific and practical conferences, data of electronic resources.

\section{Results}

The state cannot ignore the development of higher education and considers the system of higher education as a priority object of public administration, thereby harmonizing the interests of the population and the economy of the state as a whole and adopting laws and other regulations in the field of educational activities of the state related to its various directions (Mamedov, 2011,29).

You can consider the various strategic planning tools necessary for scientific support. If we consider this from the point of view of providing quality higher education, we can consider the process of implementing an interactive tool for compiling a digital curriculum, which was developed at the University of Utrecht. The tool was designed to help academic developers and supervisors in a practical discussion of the aforementioned problems and to facilitate the processes of improving the coordination of curricula and the visibility of learning paths for teachers and students. An online mapping tool offers a smart but comprehensive overview of the learning path in the curriculum (Wijngaards-de Meijet al.,2018, 219).

The lack of empirical research in the field of scientific support, as well as the theoretical contribution that helps us better understand the role and importance of this study by conducting research and sharing not only success stories, but also failure reports (Bolanderet al., 2020, 1).

Thus, we can conclude that the role of higher education and its "contribution" to the country's economy is the primary lever of economic growth.

The traditional education system as a whole is based on standard teaching methods, while the education system should be focused on how students can apply their knowledge to overcome barriers and develop their own careers. Following the innovative development path and based on the improvement of training processes using the technological infrastructure, it is possible to prepare future specialists with developed tactical and creative thinking.

Higher and postgraduate education in Kazakhstan is growing rapidly, so in the ranking of the best universities in the world Quacquarelli Symonds World University Rankings in 2017, 8 Kazakhstani universities were noted.

The results of the ranking of humanitarian and economic universities in 2020, according to the NAOKO version, indicate that among the 7 universities of Kazakhstan, the highest expert rating was given to universi- 
ties with leadership in student learning outcomes, the quality of faculty, the development of science and innovation in the digital economy (Table 1) (National rating, 2020).

Table 1. The results of the ranking of humanitarian and economic universities in 2020, according to the NAOKO

\begin{tabular}{|c|c|c|c|c|c|c|c|}
\hline № & Universityname & $\begin{array}{c}\text { University Aca- } \\
\text { demic Activities } \\
\text { and Employment } \\
\text { Results }\end{array}$ & Expertreview & $\begin{array}{l}\text { Employer } \\
\text { Reputation }\end{array}$ & $\begin{array}{c}\text { Student } \\
\text { Assessment }\end{array}$ & $\begin{array}{c}\text { Graduate } \\
\text { Assessment }\end{array}$ & $\begin{array}{l}\text { Final As- } \\
\text { sessment }\end{array}$ \\
\hline 1 & KIMEP University & 80,00 & 5,00 & 5,00 & 4,92 & 5,00 & 99,92 \\
\hline 2 & $\begin{array}{l}\text { Karaganda Economic Uni- } \\
\text { versity of Kazpotrebsoyuz }\end{array}$ & 77,58 & 4,48 & 3,79 & 4,37 & 3,91 & 94,13 \\
\hline 3 & $\begin{array}{l}\text { Almaty Management } \\
\text { University }\end{array}$ & 64,50 & 4,07 & 3,54 & 5,00 & 4,53 & 81,64 \\
\hline 4 & $\begin{array}{l}\text { Kazakh- } \\
\text { AmericanFreeUniversity }\end{array}$ & 55,84 & 3,56 & 2,88 & 4,57 & 3,88 & 70,73 \\
\hline 5 & $\begin{array}{l}\text { Kazakh University of Eco- } \\
\text { nomics, Finance and Inter- } \\
\text { national Trade }\end{array}$ & 56,41 & 4,01 & 3,09 & 4,16 & 2,89 & 70,56 \\
\hline 6 & $\begin{array}{l}\text { Academy "Bolashak" } \\
\text { (Karaganda) }\end{array}$ & 52,05 & 4,33 & 2,96 & 4,79 & 4,30 & 68,43 \\
\hline 7 & University "Turan-Astana" & 52,68 & 3,89 & 2,84 & 4,14 & 3,94 & 67,49 \\
\hline
\end{tabular}

The results of studies evaluating the readiness of higher education for the digital economy showed that only certain universities confidently passed the stages of automation, computerization and the transition to the digital economy. Most universities are in the early stages of computerization, which implies the creation of a university IT infrastructure and the computerization of educational and administrative processes. Therefore, in order to fully participate in the formation of the digital economy through training, as well as as a branch of the digital economy, it is necessary to take steps to support universities in the field of computerization.

Digital transformation allows universities to achieve a full range of unique competitive advantages and become more sustainable as they begin to develop in accordance with a new focus based on new consumer experience and new working methods.

In modern conditions, digitalization and transformation of the development strategy of higher education can become one of the active components, where the level of higher and postgraduate education is an important part of the country's integral education system (Figure 1) (Data of the Ministry of National Economy, 2018).

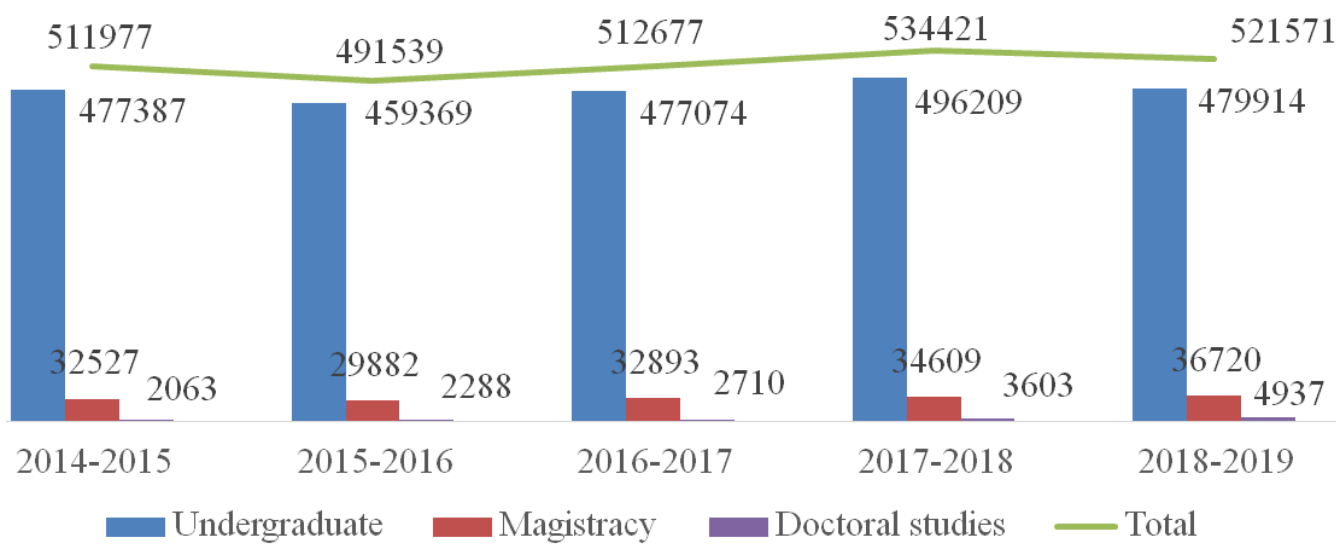

Figure 1. The contingent of universities in Kazakhstan in accordance with the three-level system of education for the period from the 2014-2019 academic years, people

Note - Compiled on the basis of the source: Electronic resource: Data of the Ministry of National Economy of the Republic of Kazakhstan for 2014-2018. //https://economy.gov.kz 
The continuity of the educational process (three-tier system) to ensure continuity of levels is one of the main principles of state policy in the field of education in Kazakhstan.

In his article, T. Eagleton notes that: "Scientific merit depends on how much money you are able to earn, while a good education is equated with employment" (Eagleton, 2010).

As Shamova TI notes, the education system is designed to carry out its transformative functions. All the links in the education system are in interaction and interconnected with each other. This objectively contributes to the integrity of the system, its unity (Shamova et al., 2002, 320).

According to Talis-2018 studies in the field of a three-level training system, the degree of Kazakhstan teachers and directors in comparison with the OECD (master's and doctoral programs) has the following indicators (Figure 2) (Syzdykbayeva, 2019).

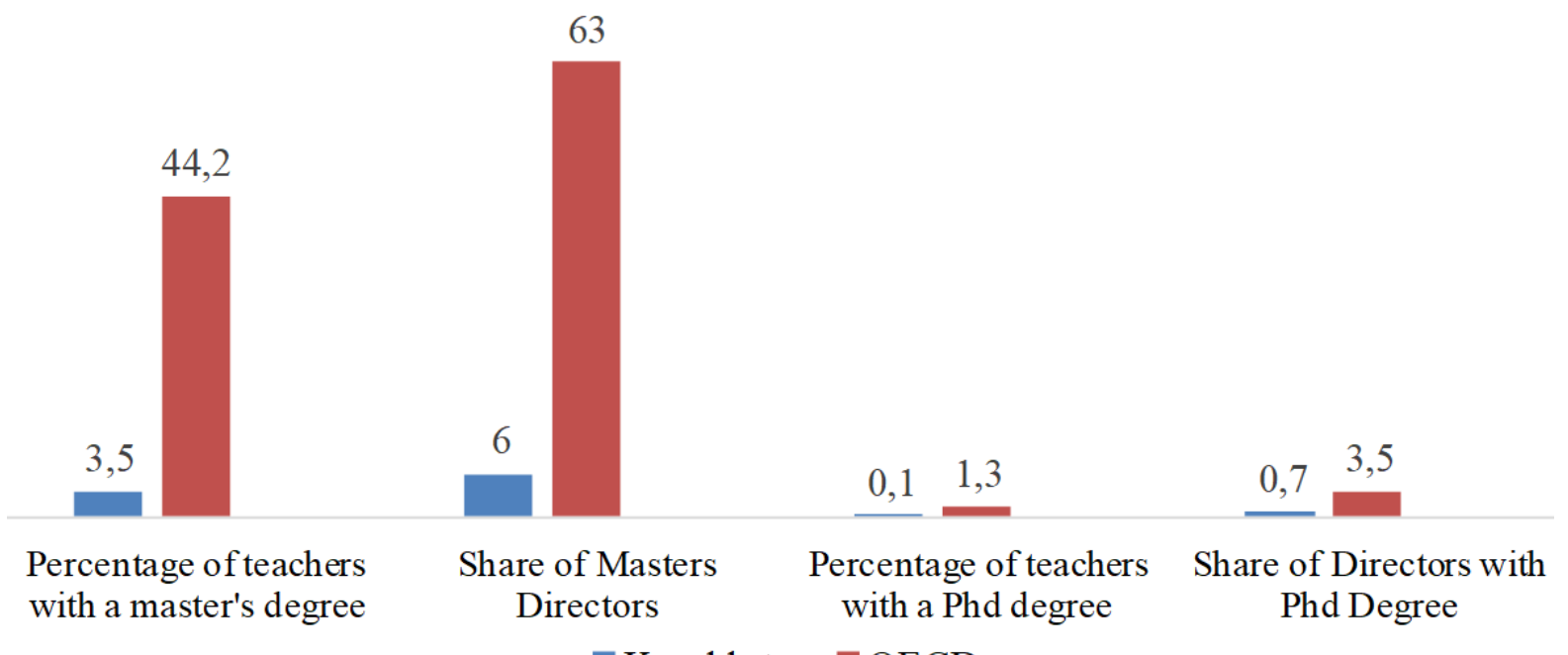

\section{Kazakhstan OECD}

Figure 2. Comparative analysis of the degree of teachers and directors of Kazakhstan and the OECD in the field of education in 2018,\%

Note - Compiled on the basis of the source: Syzdykbaeva R. "International study of teaching and learning TALIS-2018, National report, 1 volume / MES of the Republic of Kazakhstan, JSC“" Information and Analytical Center ”, Nur-Sultan: 2019. - 155 p.

Currently, the Republic of Kazakhstan has an integrated national system for assessing the quality of education at several levels, which is a comprehensive system of state control and an independent assessment of the quality of education. Incentive mechanisms were created and legislated to support the accreditation of universities (Figure 3) (Analytical report, 2018).

For example, out of 110 universities that passed institutional accreditation in agencies in 2018 included in the Register of 1, 10 national, 32 state, 18 corporatized, 1 international and 49 private universities.

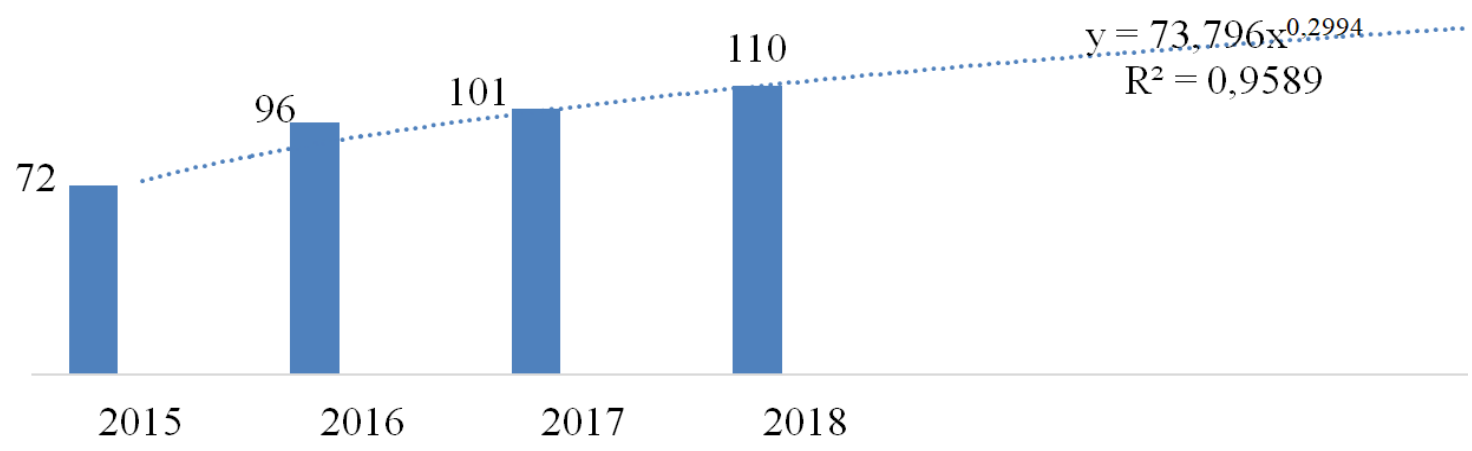

Figure 3. Dynamics of the number of universities for the period from 2015-2018, passed institutional accreditation, units

Note - Compiled on the basis of the source: Analytical report. Implementation of the principles of the Bologna process in the Republic of Kazakhstan - Astana: Center for the Bologna process and academic mobility of the Ministry of Education and Science of the Republic of Kazakhstan, 2018 - p.64 
Digitalization in higher education is a complex process of transformation and a significant increase in the effectiveness of teaching, research, extracurricular and educational activities, monitoring and measuring learning outcomes, organizational and managerial activities, which is based on the widespread use of digital technologies and resources, the basis for digitalization of universities is a digital infrastructure, which should include:

- broadband internet;

- network and server equipment;

- a park of computer equipment and peripheral equipment;

- employees with relevant professional competencies;

- Digital services and resources necessary in building effective cooperation and interaction between the university, business and regional authorities.

In modern conditions, e-learning and online education services are becoming a necessary element in the development of the digital economy under the influence of factors such as:

- technological, providing new tools and technologies for training in a modern electronic environment (Komleva,2017, 29);

- social, including the needs of society in a new quality of educational services aimed at expanding both access to education and individual needs (Mayorova, 2014, 9-14);

- economic, i.e. education has always made an important contribution to the achievement of economic indicators (Panyukova et al., 2014, 183).

According to forecasts based on OECD research, in the next 10 years, Kazakhstan will have to renew approximately $1 / 4$ of the teaching staff taking into account the increase in the level of training in digitalization (Figure 4) (Syzdykbayeva, 2019).

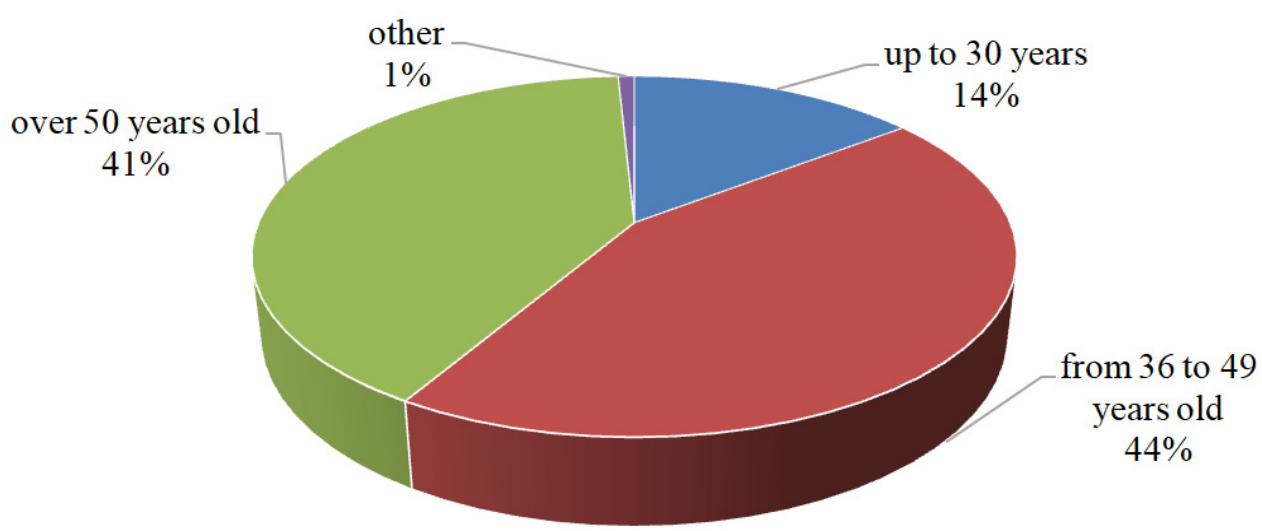

Figure 4. Forecast indicators of increasing the level of training in Kazakhstan in the context of digitalization,\%

Note - Compiled on the basis of the source: Syzdykbaeva R. "International study of teaching and learning TALIS-2018, National report, 1 volume / MES of the Republic of Kazakhstan, JSC “ Information and Analytical Center ”, Nur-Sultan: 2019. $-155 p$.

In order to increase the competitiveness, efficiency and sustainable development of higher education institutions as centers of innovative technologies and practices based on the creation of modern infrastructure and the formation of a scientific, theoretical and practical base in the methodology of the integrated use of digital systems in all types of educational activities, it is necessary to involve regional authorities to optimize innovation and business activity in order to strengthen Kazakhstani universities as a driving force for Kazakhstan's integration.

The connecting link between the university and business is innovation, which enables the university to integrate with industry, as well as the university's participation in regional integration processes (Figure 5). 


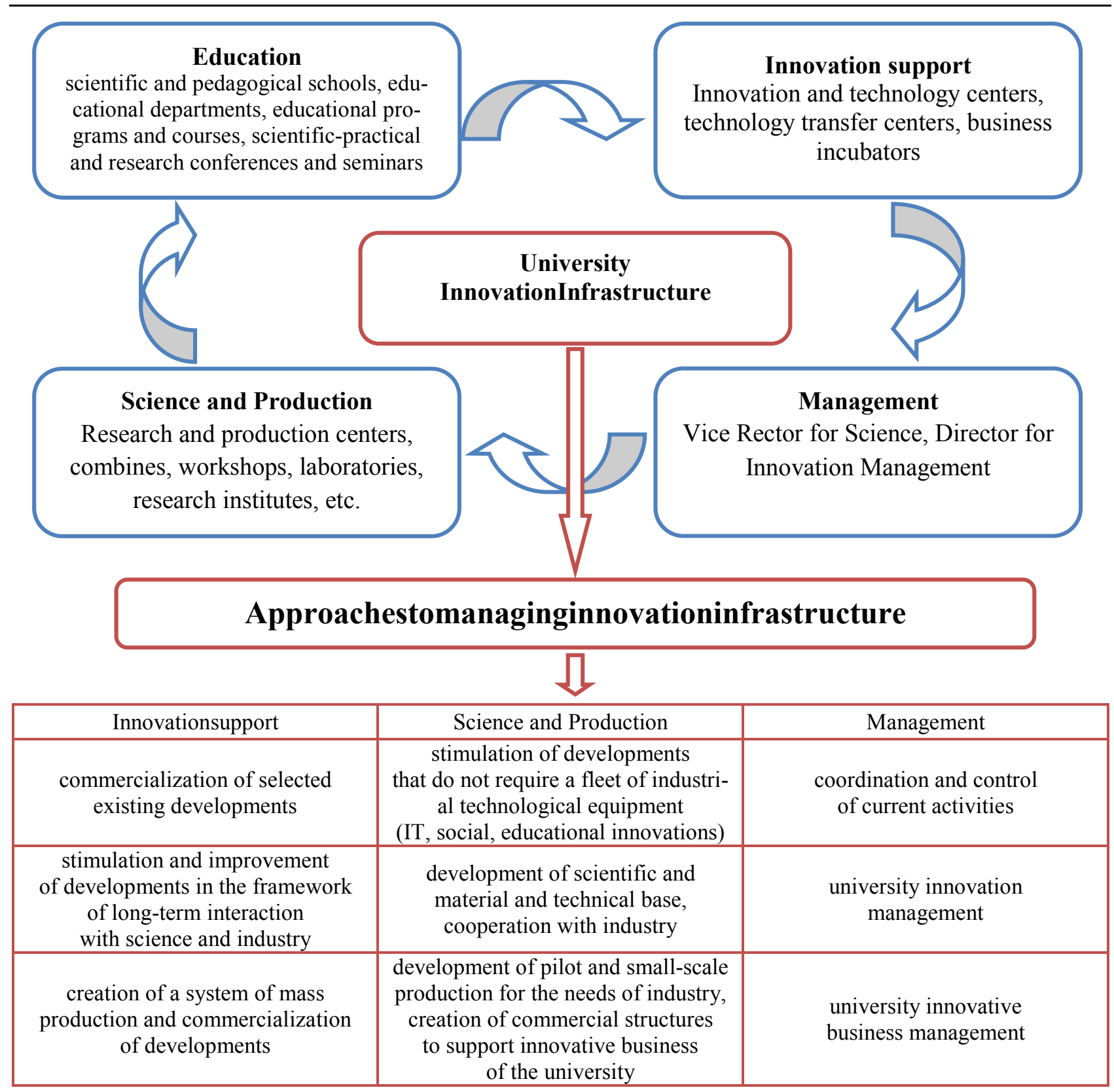

Figure 5. Features of the organization and implementation of innovative activities of the university

Note - Compiled by the author

I would like to note the fact that a distinctive feature of financing research and development in leading foreign countries is that it is implemented to a large extent at the expense of the private sector (Gulbrandsen et al., 2015, 343).

The creation of an innovation ecosystem is the creation of conditions for the development of technological entrepreneurship and innovation with stable horizontal links between business, academia and the state, where the state will act as a catalyst for an ecosystem that is able to generate, adapt and introduce innovations in production.

Today, the need of commercial organizations for qualified university staff is becoming a factor that allows universities not only to significantly increase the budget, but also to implement projects that were previously unavailable due to lack of resources.

A number of elements of the innovation ecosystem have already been created in Kazakhstan, the FEZ "PIT Alatau", AEO "Nazarbayev University" are functioning, and the international technology park Astana hub has been launched. $3 / 4$ of the adult population of the country has a basic level of digital literacy, more than $3 / 4$ have Internet access. One of the steps to creating the conditions for the transition to the information 
society was the state program "Information Kazakhstan 2020", which contributed to the development of the following factors:

- transition to the information society;

- improving public administration;

- the creation of institutions of "open and mobile government";

- increase the availability of information infrastructure not only for corporate structures, but also for citizens of the country.

The basis of the ecosystem that will be created through digital transformation will be the digitalization of basic sectors of the economy, the development of a mobile state, the formation of a creative society and the creation of a new infrastructure.

For the development of a creative society, a large role will be played by the education system across the entire vertical, including the school level. In this regard, in the framework of the program "Modernization of Public Consciousness", the government needs not only to study the most progressive world experience in transforming the education system, but also to prepare an appropriate solution taking into account the specifics of our country."

Continuing its transition from control to management strategy, the state can also stimulate the development of a culture of productivity in the education system (Figure 6) (Data of Information and Analytical Center, 2017).

It is obvious that academic and financial autonomy concerns those areas where Kazakhstan is experiencing the greatest difficulties. The reason for providing greater autonomy to educational institutions in the context of digitalization is to improve the response of higher education institutions to the needs of the country and society. This should lead to the development of more innovative potential and increased efficiency.

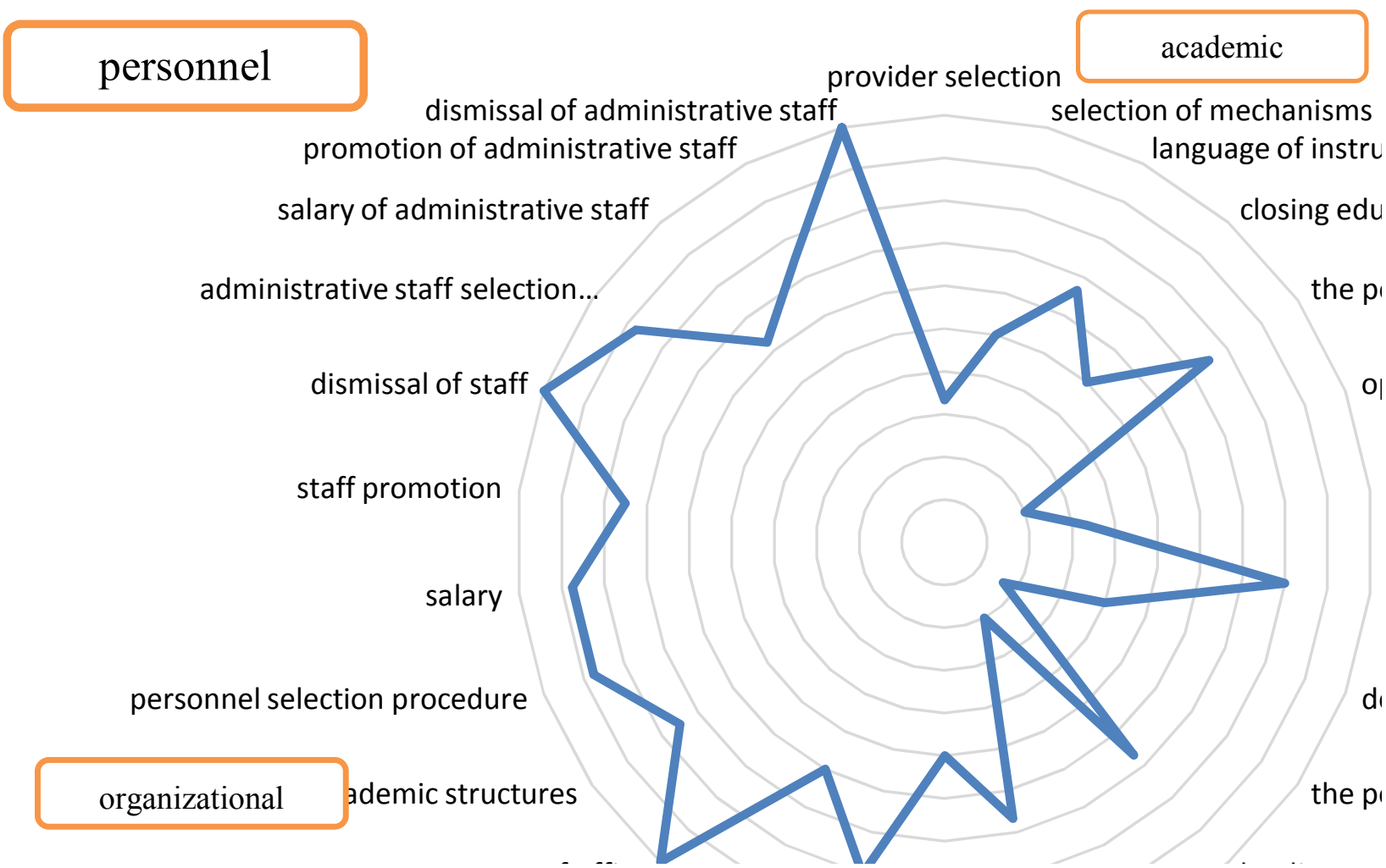

Figure 6. General assessment of the autonomy of state higher education institutions of Kazakhstan

Note - Compiled on the basis of the source: Data of Information and Analytical Center JSC, Ministry of Education and Science of the Republic of Kazakhstan - Astana, 2017.

At the same time, I would like to note that financing of higher education remains critically important in the context of digitalization and innovation policy of the state, as evidenced by the following data (Figure 7). 


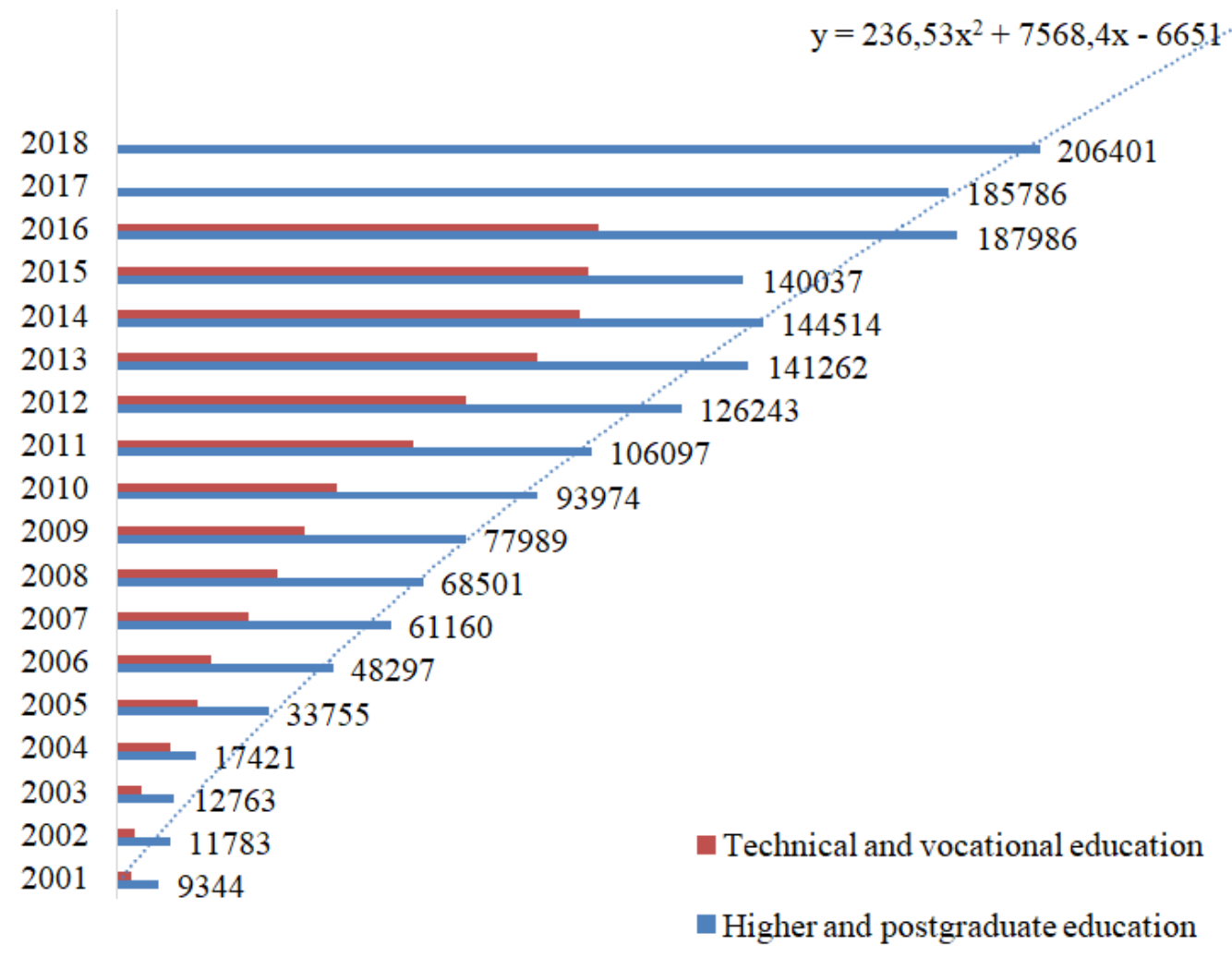

Figure 7.Public spending on education in Kazakhstan for the periodfrom 2001-2018, million tenge

Note - Compiled on the basis of the source:Electronic resource: Data of the Ministry of National Economy of the Republic of Kazakhstan for 2001-2018. //https://economy.gov.kz

An analysis was carried out of the impact on the total costs of information and communication technologies in the Republic of Kazakhstan of factors such as the cost of services rendered and goods sold, produced on their own by the universities of the Republic of Kazakhstan and internal R\&D costs.

To build an econometric model, the statistical data of these indicators for the period from 2013 to 2018 were used (Figure 8).

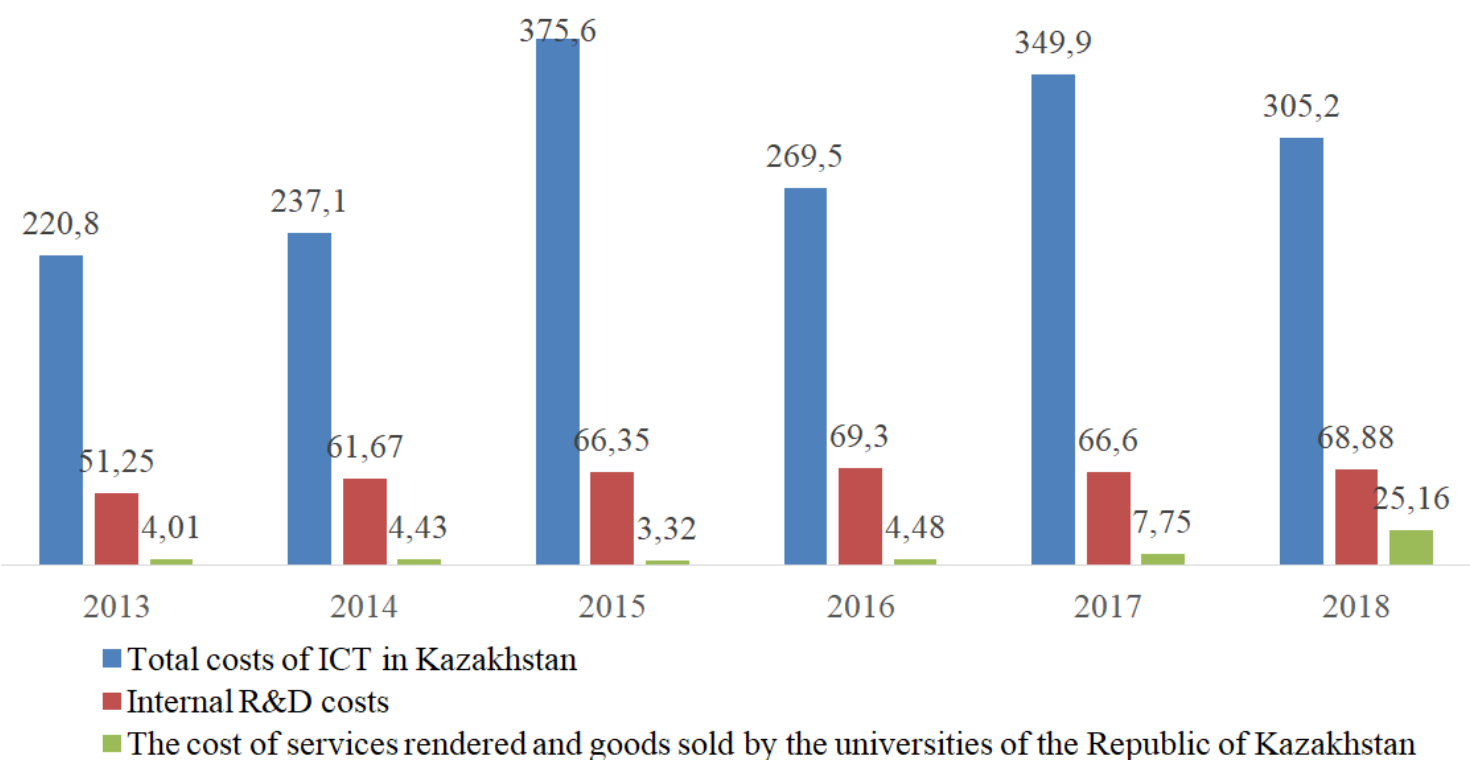

Figure 8 - Dynamics of total costs for ICT, internal costs for R\&D and the cost of services rendered and goods sold on their own by universities of the Republic of Kazakhstan for the period 2013-2018, billion tenge

Note - Compiled by the author based on the source: Electronic resource: Data of the Ministry of National Economy of the Republic of Kazakhstan for 2013-2018. //https://economy.gov.kz 
The results of the regression analysis carried out using the least squares method are shown in Table 2 .

Table 2 - The results of evaluating the equation of total costs for information and communication technologies in the Republic of Kazakhstan

\begin{tabular}{|l|l|}
\hline$R$ & 0,761 \\
\hline$R^{2}$ & 0,578 \\
\hline The observed value of the Fisher test & 5,613 \\
\hline Fisher's criterion critical & $5,462\left(\alpha=0,1, k_{1}=2, \quad k_{2}=3\right)$ \\
\hline Variables \\
\hline Total costs of ICT in the Republic of Kazakhstan (billion tenge) - dependent variable \\
\hline Constant & $-93,027^{*}$ \\
\hline & Regression coefficients \\
\hline Internal R\&D costs & $6,143^{*}$ \\
\hline $\begin{array}{l}\text { The cost of services rendered and goods } \\
\text { sold, produced on their own, by universi- } \\
\text { ties of the Republic of Kazakhstan }\end{array}$ & $0,878^{*}$ \\
\hline$* \mathrm{p}<0,1 ; * * \mathrm{p}<0,05 ; * * * \mathrm{p}<0,01$ & \\
\hline Note - Compiled by the author & \\
\hline
\end{tabular}

The multiple correlation coefficient indicates the average relationship of the resulting trait with two factorial traits simultaneously, and the determination coefficient indicates that $57.8 \%$ of the variation in the dependent variable is explained by the resulting regression. The resulting regression equation as a whole and its individual parameters are statistically significant and reliable with a $90 \%$ probability.

Analysis of the parameters of the multiple linear regression equation allows us to draw the following conclusions:

1) with an increase in internal expenditures on R\&D by 1 billion tenge, the total expenditures on ICT increase by an average of 6.143 billion tenge;

2) with an increase in the cost of services rendered and goods sold, produced on their own, by the universities of the Republic of Kazakhstan by 1 billion tenge, the total cost of ICT increases by an average of 0.878 billion tenge.

One of the indicators that can be used to assess the degree of response of one variable to a change in another is the coefficient of elasticity. In our case, it will show the ability of the total costs of ICT to change depending on changes in internal costs for $R \& D$ and the cost of services rendered and goods sold, produced on their own, by universities of the Republic of Kazakhstan.

Thefollowingvaluesoftheaggregateaverageelasticitycoefficientswereobtained:

$$
\bar{E}_{1}=1,342 \%, \quad \bar{E}_{2}=0,025 \% .
$$

Having analyzed these coefficients of elasticity, we get that:

1) with an increase in internal cdsts for $R \& D$ by $1 \%$ of its average level, the total costs of ICT will increase by $1.342 \%$ of their average level, with the cost of services rendered and goods sold, produced on their own, by the universities of the Republic of Kazakhstan unchanged;

2) with an increase in the cost of services rendered and goods sold, produced on their own, by the universities of the Republic of Kazakhstan by $1 \%$ of their average level, the total costs of ICT will increase by $0.025 \%$ of their average level, with the volume of internal R\&D costs unchanged.

As a result of the analysis, the author concluded that the use of new information and communication technologies is a necessary condition for the further development of education and digital pedagogy, since the implementation of an effective information educational environment is the basis for the development of any university.

The introduction of digitalization technologies that allow the university, government, business and society to effectively interact is becoming an increasingly large-scale and dynamic process, since the digitalization process makes it possible to improve solutions and business processes for more efficient work and optimize resources with even greater benefit.

Technological modification enhances the process of differentiation and specialization in higher education, as digitalization of higher education changes the qualification requirements for the teaching staff and the rest of the university staff, through the integration of digital methods in education. 
Thus, the processes of globalization and technological modernization in the digital economy contribute to the emergence of new areas of knowledge, as well as the obsolescence or practical uselessness of existing areas. In such conditions, universities should offer new forms of education aimed at a qualitatively new level of training of Kazakhstani specialists, adapted to the global competition for knowledge.

\section{Discussion}

The article discusses the strategies of universities in the context of digitalization of education and the interaction of universities, government bodies and business, the efforts of which lead to the creation of a new society in which human capital is actively developing - the knowledge and skills of the future are raised from an early age, increasing business efficiency and speed through automation and other new technologies.

To achieve this goal, the study was based on such methods of assessing the readiness of education in Kazakhstan in the context of digitalization, such as:

- The use of information technology in the educational process;

- training of teaching staff in the field of the use of information technology in education;

- computerization of education management;

- information infrastructure of higher education;

- Legal and administrative support for the digitalization of education.

Based on the conducted regression analysis, the author of the article put forward hypotheses about the existence of a relationship between the total costs of ICT and the cost of services provided by the universities of the Republic of Kazakhstan and the costs of ICT and scientific costs of R\&D in the Republic of Kazakhstan, as a result of which, it was concluded that the use of new information -communication technology is a prerequisite for the further development of education and digital pedagogy, since the implementation of an effective information educational environment is the basis for the development of any university.

\section{Conclusion}

An analysis of the participation of universities, the role of the state and the business community in the digitalization of the educational space showed that there are certain benefits, that is, the effect of digitalization:

1) Economic:

- contribution to GDP, economic growth;

- reduction of unemployment, increase in the number of qualified personnel;

- the growth of labor productivity indicators;

- development of small and medium-sized businesses;

- link integration

- Transformation of the industry.

2) Social benefits:

- reduction of poverty;

- accessibility of information and communication services;

- availability of financial services;

- the availability of education, medical care.

Based on the foregoing, it can be concluded that digitalization in the system of transforming the educational space is relevant today for the development of any country, which can lead to the emergence of smart cities, transport and agriculture, the absence of digital inequality in certain regions and an increase in the level of digital literacy of the population. Therefore, as priority areas of modernization of the higher education system in Kazakhstan, in accordance with the State Program for the Development of Education and Science of the Republic of Kazakhstan for 2020-2025, we can distinguish:

- introduction of programs of professional competency-based approach in higher education taking into account social order in the framework of creating an innovative educational system of an international type;

- ensuring real multi-level higher education, the creation of modern university complexes;

- transition to a qualitatively new model of education (optimization of teaching methods, the active use of open education technologies;

- deepening integration and interdisciplinary programs at the higher school, combining them with breakthrough high technologies, practical orientation of the educational process at the university);

- An individual approach to the organization of the learning process, taking into account the personal capabilities and needs of the student in the framework of the conditions determined by the university;

- openness and rationality of the organizational structure of the university; 
- increasing the competitiveness of educational institutions in the educational services market (for this purpose, the university will develop an effective image policy and marketing strategies for its implementation);

- improvement of university management on the principles of openness and democratization and the formation of a high corporate culture;

- further internationalization of education at the university through the processes of academic mobility of students and teachers, internationalization of student contingent and innovative pedagogical experience;

- raising the status of university science as part of the expansion of the commercialization of scientific achievements, the integration of university science, the business environment and production (On approval of the State Program, 2019).

\section{References}

Bolander, K. \& McGrath, C. (2020). Failure as a catalyst for learning: towards deliberate reflection in academic development work. International Journal for Academic Development, 1(25), 1-4. https://doi.org/10.1080/ 1360144X.2020.1717783

Eagleton, T. (2010).The Death of Universities.The Guardian. Retrieved from https://www.theguardian.com/commentisfree/2010/dec/17/death-universities-malaise-tuition-fees

Etzkowitz, H., Ranga, M., Dzisah, J. \&Zhou,C.(2007).University-IndustryGovernment Interaction: the Triple Helix Model of Innovation.Asia Pacific Tech, 24 (1), 14-23.

Gulbrandsen, M. \&Kyvik, S. (2015). Are the concepts basic research, applied research and experimental development still useful? An empirical investigation among Norwegian academics.Science and Public Policy, 5(37), $343-353$.

Sutherland, K.A. (2018). Holistic academic development: Is it time to think more broadly about the academic development project? International Journal for Academic Development, 4(23), 261-273.

Wijngaards-de Meij, L., \& Merx, S. (2018). Improving curriculum alignment and achieving learning goals by making the curriculum visible. International Journal for Academic Development, 3(57), 219-231.

Analiticheskii otchet. Realizatsiia printsipov Bolonskoho protsessa v Respublike Kazakhstan (2018) [Analytical report.Implementation of the principles of the Bologna process in the Republic of Kazakhstan]. Tsentr Bolonskoho protsessaiak ademicheskoi mobilnosti MON RK - Center for the Bologna process and academic mobility of the Ministry of Education and Science of the Republic of Kazakhstan, 64. Astana [in Russian].

Vakhshtayn, V.S., Zhelezov, B.V. \& Meshkova, T.A. (2014). Osnovnye endentsii hosudarstvennoi politiki v sfere vyssheho obrazovaniia $\mathrm{v}$ stranakh OESR [The main trends of state policy in the field of higher education in the OECD countries]. Sotsialno-humanitarnye znaniya - Social and humanitarian knowledge, 6, 32-46.

Veduta, Ye.N. \& Dzhakubova, T.N. (2017). Big Data Ekonomicheskaia kibernetika [Big Data and Economic Cybernetics]. Hosudarstvennoe upravlenie. Elektronnyi vestnik - Public Administration.Electronic bulletin, 63, 43-66 [in Russian].

Hosudarstvennaia prohramma «Tsifrovoi Kazakhstan» (2017) [The state program “Digital Kazakhstan"]. Retrieved from https://online.zakon.kz/document/?doc_id=37168057

Dannye AO «Informatsionno-analiticheskii tsentr», Ministerstvo obrazovaniia i nauki Respubliki Kazakhstan (2017) [Data of Information and Analytical Center JSC, Ministry of Education and Science of the Republic of Kazakhstan]. Retrieved from http://iac.kz/ [in Russian].

Dannye Ministerstva natsionalnoi ekonomiki RK za 2013-2018 hh. (2018) [Data of the Ministry of National Economy of the Republic of Kazakhstan for 2013-2018]. Retrieved from https://economy.gov.kz

Kazakhstanskii put - 2050: Yedinaia tsel, edinye interesy, edinoe budushchee (2014) [Kazakhstan's way - 2050: One goal, common interests, common future]. Retrieved from http://www.akorda.kz

Komleva, N.V. (2017). Professionalnaia kompetentnost lichnosti v usloviiakh Smart-obshchestva [Professional competence of a person in a Smart-society]. Otkrytoe obrazovanie - Open Education, 1, 27-33. Retrieved from DOI:10.21686/1818-4243-2017-1-27-33 [in Russian].

Kulyutkin, Yu.N. \& Bezdukhov, V.P. (2002).Tsennostnye orientiry i kohnitivnye struktury v deiatelnosti uchitelia [Value orientations and cognitive structures in teacher's activity]. Samara - Samara, 44. Retrieved from http://www.bim-bad.ru/docs/kuljutkin_bezduhov_uchitel.pdf [in Russian].

Mayorova, N.V. (2014). Otnoshenie naseleniia k problem vliianiia obrazovaniia i nauki na razvitiie obshchestva [The attitude of the population to the problem of the influence of education and science on the development of society]. Statistikai ekonomika - Statistics and Economics, 6, 9-14. Retrieved from https://doi.org/10.21686/2500-392520146-9-14 .[in Russian].

Mamedov, A.A. (2011). Hosudarstvennoe rehulirovanie v sfere vyssheho obrazovaniia [State regulation in the field of higher education]. Vestnik RUDN «Yuridicheskie nauki» - Bulletin of the RUDN University "Legal Sciences", 2, 29 [in Russian].

Natsionalnyi reitinh luchshikh vuzov Kazakhstana 2020 (2020) [National rating of the best universities in Kazakhstan 2020] // Kazakhstanskaia pravda - Kazakhstanskaya Pravda, 103. Retrieved from https://www.kazpravda.kz/fresh/view/natsionalnii-reiting-luchshih-vuzov-kazahstana-2020 [in Russian]. 
Nurtayeva, D.K. Pospelova, T.V. \& Nurmukhanova, G.Zh. (2019). Rol sovremennykh universitetov v formirovani i ekonomiki znaniy v usloviiakh industrii 4.0 [The role of modern universities in the formation of the knowledge economy in the context of industry 4.0]. Materialy mezhdunarodnoi nauchno-prakticheskoi konferentsii "Innovatsionno-predprinimatelskoe obrazovanie v kontekste povysheniia kachestva zhizni» - Materials of the international scientific-practical conference "Innovative and entrepreneurial education in the context of improving the quality of life", 27-34 [in Russian].

Ob utverzhdenii Hosudarstvennoi prohrammy razvitiia obrazovaniia i nauki Respubliki Kazakhstan na 2020-2025 hody (2019) [On approval of the State Program for the Development of Education and Science of the Republic of Kazakhstan for 2020-2025]. № 988. Retrieved from https://online.zakon.kz/Document/?doc_id=33927070\#pos=11;50 [in Russian].

Panyukova, S.V., Gostin, A.M. \& Avilkina, S.V. (2014). Upravlenie chelovecheskim kapitalom v usloviiakh informatsionnoho obshchestva [Human capital management in the information society]. Statistika i ekonomika Statistics and Economics, 1, 183-186. Retrieved from https://doi. org/10.21686/2500-3925-2014-1-183-186 [in Russian].

Stratehiia 2050 (2012). [Strategy 2050]. Stratehii i prohrammy Respubliki Kazakhstan Ofitsialnyi sait Prezidenta Respubliki Kazakhstan - Strategies and programs of the Republic of Kazakhstan Official website of the President of the Republic of Kazakhstan. Retrieved from http://www.akorda.kz/ [in Russian].

Syzdykbayeva, R. (2019). Mezhdunarodnoe issledovanie prepodavaniia i obucheniia TALIS-2018: pervye rezultaty Kazakhstana. Natsionalnyi otchet [International study of teaching and learning TALIS-2018: the first results of Kazakhstan. National Report]. Ministerstvo obrazovaniia i nauki Respubliki Kazakhstan, AO «Informatsionnoanaliticheskii tsentr» - Ministry of Education and Science of the Republic of Kazakhstan, JSC "Information and Analytical Center", 1, 155. Nur-Sultan [in Russian].

Fayol', A. (2012). Obshchee i promyshlennoe upravlenie [General and industrial management]. Elektronnaia publikatsiia - Electronic publication, 8 [in Russian].

Chinayeva, T.I. (2017). Osnovnye tendentsii razvitiia mezhdunarodnoho rynka obrazovatelnykh usluh [The main trends in the development of the international market for educational services]. Statistikai ekonomika - Statistics and Economics, 1, 60-68. Retrieved from https://doi.org/10.21686/2500-3925-2017-1-6068 [in Russian].

Shamova, T.I., Tret'yakov, P.I. \& Kapustin, N.P. (2002). Upravleniie obrazovatelnymi sistemami [Management of educational systems]. Uchebnoe posobie dlia vuzov, Vlados - Textbook for universities, Vlados, 320. [in Russian].

Yuvitsa, N.V. (2015). Stratehicheskoie planirovanie i hosudarstvennyi menedzhment Kazakhstana [Strategic planning and state management of Kazakhstan]. Mezhdunarodnyi zhurnal eksperimentalnoho obrazovaniia - International Journal of Experimental Education, 3(2), 247-249. Retrieved from http://www.expeducation.ru/ru/article/view? $\mathrm{id}=6832$ [in Russian].

\section{Р.Б. Жашкенова, Е.Б. Аймагамбетов, Т.П. Притворова, А.Т. Омарова, Г.Е. Накипова}

\section{Университеттер стратегияларын білім беру кеңістігін сандықтандыру жағдайында трансформациялау}

\section{Ацдатпа}

Maқ̧cambl: Сандықтандыру аясында университеттердің мемлекет және бизнес-қоғамдастықпен өзара әрекеттесу саласындағы стратегияларын трансформациялауға арналған сандық экономика жағдайындағы университеттер стратегиясын талдау.

Әдістер: Зерттеу әдістемесін кез келген университеттің дамуына негіз болатын тиімді ақпараттық білім беру ортасын іске асыруда білім беру мен цифрлық педагогиканы одан әрі дамытудың алғышарты болып табылатын жаңа ақпараттық-коммуникациялық технологияларды дамыту мен пайдаланудың тиімділігін арттыруға арналған әдістердің, механизмдердің, принциптердің, шаралардың жиынтығы құрайды.

Нәтижелері: ҚР ЖОО-ларының өздері өндірген қызметтері мен сатылған тауарларының өзіндік құны және Қазақстан Республикасындағы ҒЗТКЖ-ның ішкі шығындары сияқты көрсеткіштер үшін авторлар мыналар арасында байланыс бар деп жорамалдады: АКТ жалпы шығындары мен Қазақстан Республикасының жоғары оқу орындары ұсынатын қызметтердің құны; АКТ бойынша шығындар және Қазақстан Республикасындағы ҒЗТКЖ-ға ғылыми шығындары.

Қорытынды: Жасалған регрессиялық талдау негізінде мақала авторлары мынадай қорытынды жасады:

1) ҒЗТКЖ-ға жұмсалатын ішкі шығыстардың орташа деңгейінің 1\% -ға өсуімен АКТ-ға жалпы шығыстар олардың орташа деңгейінің 1,342\% өседі, бұл ретте Қазақстан Республикасының жоғары оқу орындары өндіретін қызметтер мен сатылатын тауарлардың құны өзгермейді;

2) Қазақстан Республикасының жоғары оқу орындары ұсынатын қызметтер мен сатылған тауарлардың өзіндік құны өндірілген өнімнің өзіндік деңгейінің орташа деңгейінің 1\% -ға өсуімен АКТ-ның жалпы шығындары олардың орташа деңгейінің 0,025\% -на өседі, ал ішкі ғылыми-зерттеу шығындарының көлемі өзгеріссіз қалады. 
Kiлm сөздер: сандықтандыру, бизнес-қауымдастық, стратегия, білім беру жүйесі, инновация, инновациялық, бәсекеге қабілеттілік, білім беру үрдісі, басқару, сапа, білім беру кеңістігі.

\section{Р.Б. Жашкенова, Е.Б. Аймагамбетов, Т.П. Притворова, А.Т. Омарова, Г.Е. Накипова}

\section{Трансформация стратегии университетов в условиях цифровизации образовательного пространства}

\section{Аннотация}

Цель: Цель заключается в анализе стратегии университетов в контексте цифровой экономики, где акцент делается на трансформацию стратегии вузов в области взаимодействия их с государством и бизнессообществом в условиях цифровизации.

Memoдbl: Методологию исследования составляет комплекс методов, механизмов, принципов, мероприятий по повышению эффективности развития и использования новых информационно-коммуникационных технологий, которые являются необходимым условием для дальнейшего развития образования и цифровой педагогики, в реализации эффективной информационной образовательной среды, являющейся основой развития любого вуза.

Результаты: Авторами для таких показателей, как стоимость оказанных услуг и реализованных товаров, произведенных своими силами вузами РК, и внутренними затратами на НИОКР в РК, были выдвинуты гипотезы о наличии связи между общими расходами на ИКТ и стоимостью услуг, которые оказывают вузы РК; расходами на ИКТ и научными затратами на НИОКР в РК.

Bblвoдbl: На основе проведенного регрессионного анализа авторами статьи были сделаны выводы:

1) при увеличении внутренних затрат на НИОКР на 1\% от своего среднего уровня общие затраты на ИКТ увеличатся на 1,342 \% от своего среднего уровня при неизменной стоимости оказанных услуг и реализованных товаров, произведенных своими силами вузами РК;

2) при росте стоимости оказанных услуг и реализованных товаров, произведенных своими силами вузами РК на $1 \%$ от своего среднего уровня, общие затраты на ИКТ увеличатся на 0,025 \% от своего среднего уровня при неизменном объеме внутренних затрат на НИОКР.

Ключевые слова: цифровизация, бизнес-сообеесво, стратегия, система образования, инновация, инновационность, конкурентоспособность, образовательный процесс, управление, качество, образовательное пространство.

\section{References}

Bolander K. Failure as a catalyst for learning: towards deliberate reflection in academic development work [Tекст] / K. Bolander, C. McGrath // International Journal for Academic Development. — 2020. — Vol. 25, № 1. — P. 1-4. - Access mode: https://doi.org/10.1080/1360144X.2020.1717783.

Eagleton T. The Death of Universities [Текст] / T. Eagleton // The Guardian. — 2010. — Access mode: https://www.theguardian.com/commentisfree/2010/dec/17/death-universities-malaise-tuition-fees

Etzkowitz H. University-Industry Government Interaction: the Triple Helix Model of Innovation [Tекст] / H. Etzkowitz, M. Ranga, J. Dzisah, C.Zhou // Asia Pacific Tech. — 2007. — № 24 (1). — P. 14-23.

Gulbrandsen M. Are the concepts basic research, applied research and experimental development still useful? An empirical investigation among Norwegian academics [Текст] / M. Gulbrandsen, S. Kyvik // Science and Public Policy. — 2015. - Vol. 37, № 5. - P. 343-353.

Sutherland K.A. Holistic academic development: Is it time to think more broadly about the academic development project? [Текст] / K.A. Sutherland // International Journal for Academic Development. — 2018. — № 23(4). P. 261-273.

Wijngaards-de Meij, L. Improving curriculum alignment and achieving learning goals by making the curriculum visible [Текст] / L. Wijngaards-de Meij, S. Merx // Journal International Journal for Academic Development. — 2018. — Vol. 23, № 3. - P. 219-231

Аналитический отчет «Реализация принципов Болонского процесса в Республике Казахстан» [Текст] // Центр Болонского процесса и академической мобильности МОН РК. — Астана, 2018. — С. 64.

Вахштайн В.С. Основные тенденции государственной политики в сфере высшего образования в странах ОЭСР [Текст] / В.С. Вахштайн, Б.В. Железов, Т.А. Мешкова // Социально-гуманитарные знания. — 2014. — № 6. - C. 32-46.

Ведута E.H. BigData и экономическая кибернетика [Текст] / Е.Н. Ведута, Т.Н. Джакубова // Государственное управление // Электрон. вестн. - 2017. — № 63. - С. 43-66.

Государственная программа «Цифровой Казахстан» [Текст] // Постановление Правительства Республики Казахстан от 12 декабря 2017 года № 827. - Режим доступа: https://online.zakon.kz/document/? doc_id=37168057.

Данные АО «Информационно-аналитический центр»; Министерства образования и науки Республики Казахстан. - Астана, 2017. - Режим доступа: http://iac.kz/ 
Данные Министерства национальной экономики РК за 2013-2018. — Режим доступа:https://economy.gov.kz Казахстанский путь - 2050: Единая цель, единые интересы, единое будущее [Текст] // Послание Первого Президента РК Н.А. Назарбаева народу Казахстана от 17 января 2014 г. — Режим доступа: http://www.akorda.kz.

Комлева Н.В. Профессиональная компетентность личности в условиях Smart-общества [Текст] / Н.В. Комлева // Открытое образование - 2017. — № 1. — C. 27-33. — DOI:10.21686/1818-4243-2017-1-27-33.

Кулюткин Ю.Н. Ценностные ориентиры и когнитивные структуры в деятельности учителя [Текст] / Ю.Н. Кулюткин, В.П. Бездухов. - Самара, 2002. - С. 44. - Режим доступа: http://www.bimbad.ru/docs/kuljutkin_bezduhov_uchitel.pdf

Майорова Н.В. Отношение населения к проблеме влияния образования и науки на развитие общества [Текст] / Н.В. Майорова // Статистика и экономика - 2014. - № 6. - С.9-14. — Режим доступа: https://doi.org/10.21686/2500-3925-20146-9-14

Мамедов А.А. Государственное регулирование в сфере высшего образования [Текст] / А.А. Мамедов // Вестн. РУДН Сер. Юридические науки. - 2011. - № 2. - С. 29.

Национальный рейтинг лучших вузов Казахстана 2020 [Текст] // Казахстанская правда. — № 103. 2020 г. - Режим доступа: https://www.kazpravda.kz/fresh/view/natsionalnii-reiting-luchshih-vuzov-kazahstana2020

Нуртаева Д.К., Поспелова Т.В., Нурмуханова Г.Ж. Роль современных университетов в формировании экономики знаний в условиях Индустрии 4.0 [Текст] : материалы Междунар. науч.-практ. конф. «Инновационнопредпринимательское образование в контексте повышения качества жизни». - Алматы, 2019. — С. 27-34.

Об утверждении Государственной программы развития образования и науки Республики Казахстан на 2020 2025 годы [Текст] // Постановление Правительства Республики Казахстан от 27 декабря 2019 года. - № 988. — Режим доступа: https://online.zakon.kz/Document/? doc_id=33927070\#pos=11;-50

Панюкова С.В. Управление человеческим капиталом в условиях информационного общества [Текст] / С.В. Панюкова, А.М. Гостин, С.В. Авилкина // Статистика и экономика — 2014. — № 1. — C. 183-186. — Режим доступа: https://doi. org/10.21686/2500-3925-2014-1-183-186

Стратегия 2050 [Текст] / Стратегии и программы Республики Казахстан. Официальный сайт Президента Республики Казахстан от 14 декабря 2012 г. - Режим доступа: http://www.akorda.kz.

Сыздыкбаева Р. Международное исследование преподавания и обучения TALIS-2018: первые результаты Казахстана. Национальный отчет [Текст] / Р. Сыздыкбаева // Министерство образования и науки Республики Казахстан; АО «Информационно-аналитический центр». - Т. 1. - Нур-Султан, 2019. - С. 155.

Файоль А. Общее и промышленное управление [Текст] / А. Файоль // Электронная публикация. — M., 2012. — C. 8.

Чинаева Т.И. Основные тенденции развития международного рынка образовательных услуг [Текст] / Т.И. Чинаева // Статистика и экономика - 2017. - № 1. - С. 60-68. - Режим доступа: https://doi.org/10.21686/2500-3925-2017-1-6068.

Шамова Т.И. Управление образовательными системами [Текст]: учеб. пос. для вузов / Т.И. Шамова, П.И. Третьяков, Н.П. Капустин. - М.: Владос, 2002. - С. 320.

Ювица Н.В. Стратегическое планирование и государственный менеджмент Казахстана: моногр. [Текст] / Н.В. Ювица // Междунар. журн. эксперим. обр. - М.: Изд. НИЦ «Академия естествознания», 2015. — № 3-2. - С. 247-249. - Режим доступа: http://www.expeducation.ru/ru/article/view? id=6832 